\title{
Feeding Habits of Predatory Thermophilic Fish Species and Species with Subtropical Affinity from Recently Extended Distributional Range in Northeast Adriatic Sea, Croatia
}

\author{
Neven Iveša ${ }^{1}$, Marina Piria ${ }^{2, *} \mathbb{C}$, Martina Gelli ${ }^{1}$, Thomas Trnski ${ }^{3}$, Ivan Špelić ${ }^{2}$, , Tena Radočaj ${ }^{2}$, \\ Kristina Kljak ${ }^{4} \oplus$, Jurica Jug-Dujaković ${ }^{5}$ and Ana Gavrilović ${ }^{2}$ \\ 1 Department of Natural and Health Sciences, University of Pula, Zagrebačka 30, 52100 Pula, Croatia; \\ nivesa@unipu.hr (N.I.); martina.gelli@unipu.hr (M.G.) \\ 2 Department of Fisheries, Apiculture, Wildlife Management and Spec. Zoology, University of Zagreb Faculty \\ of Agriculture, Svetošimunska Cesta 25, 10000 Zagreb, Croatia; ispelic@agr.hr (I.Š.); tradocaj@agr.hr (T.R.); \\ agavrilovic@agr.hr (A.G.) \\ 3 Tāmaki Paenga Hira Auckland Museum, Private Bag 92018, Victoria St West, Auckland 1142, New Zealand; \\ ttrnski@aucklandmuseum.com \\ 4 Department of Animal Nutrition, University of Zagreb Faculty of Agriculture, Svetošimunska Cesta 25, \\ 10000 Zagreb, Croatia; kkljak@agr.hr \\ 5 Sustainable Aquaculture Systems Inc., 715 Pittstown Road, Frenchtown, NJ 08825, USA; \\ J.Jug-Dujakovic@sasi-usa.com \\ check for \\ * Correspondence: mpiria@agr.hr
}

updates

Citation: Iveša, N.; Piria, M.; Gelli, M.; Trnski, T.; Špelić, I.; Radočaj, T.; Kljak, K.; Jug-Dujaković, J.; Gavrilović, A. Feeding Habits of Predatory Thermophilic Fish Species and Species with Subtropical Affinity from Recently Extended Distributional Range in Northeast Adriatic Sea, Croatia. Diversity 2021, 13, 357. https://doi.org/10.3390/ d13080357

Academic Editor: Michael Wink

Received: 29 June 2021

Accepted: 31 July 2021

Published: 3 August 2021

Publisher's Note: MDPI stays neutral with regard to jurisdictional claims in published maps and institutional affiliations.

Copyright: (c) 2021 by the authors. Licensee MDPI, Basel, Switzerland. This article is an open access article distributed under the terms and conditions of the Creative Commons Attribution (CC BY) license (https:// creativecommons.org/licenses/by/ $4.0 /)$.
Abstract: The study investigates feeding habits of thermophilic species and species with subtropical affinity in the fishing catch in the Bay of Medulin (northeastern Adriatic Sea), and contributes to the knowledge about their presence in recently extended distributional range. In our methodology, the presence of the Seriola dumerili, Sphyraena sphyraena, Lichia amia, Coryphaena hippurus, Caranx crysos, Pomatomus saltatrix, and incidence of Trachinotus ovatus is recorded. A total of 220 specimens are captured during 2017, 2018 and 2019. A dietary assessment is performed, and the index of relative importance IRI was calculated for each prey category. Diet overlap is calculated using Schoener's index, based on IRI. The principal diet of C. hippurus included Sardina pilchardus and Loligo vulgaris. Pomatomus saltatrix consumed species from the Sparidae family and T. ovatus crustaceans from the Mysidacea family. Different species from genus Atherina are represented important foods for L. amia, S. dumerili and S. sphyraena. Diets of significant importance for L. amia included fishes from the family Sparidae, for S. sphyraena from the Carangidae family, and S. dumerili from the Clupeidae and Muliidae families. Our analysis of diet overlap is based on IRI suggests no diet overlap between analysed fish species from Medulin Bay, and that these species utilise differing trophic niches.

Keywords: marine fish; extended distributional range; North Adriatic; Istria

\section{Introduction}

The Mediterranean Sea is a marine biodiversity hotspot [1]. It is also an ecoregion impacted by severe biodiversity threats [2], mostly because of the ongoing warming trend, due to climate change [3]. Changes in biochemical and physical properties of seawater, resulting from global warming, are likely to alter marine biodiversity, trigger trophic web mismatches, encourage diseases and toxic algal blooms, and encourage the propagation of thermophilic species [4].

Climatic conditions of the Mediterranean Sea are characterised by cold winters in the northern region, and long and warm summers in the south $[3,5,6]$, influencing the distribution of ichthyofauna. Subtropical species are commonly found in warmer eastern and southern parts, Lessepsian migrants in the south, and Atlantic migrants in the west; while boreal species reside in the northern regions $[1,7,8]$. At the end of the 20th and 
beginning of the 21st century in the Atlantic, as well as in the Mediterranean, the widening of the range of distribution of thermophilic fish species and species with subtropical affinity has been observed in the northern parts, where they were previously not present or were rarely recorded [9-12]. Additionally, the number of allochthonous thermophilic species has increased, leading to changes in infralittoral communities, reduced genetic diversity, a loss of function and structure of habitats, and an increased risk of biotic homogenisation [13-15]. The invasion of non-native species will continue to alter local biodiversity records, mainly in its eastern basin, which can spread rapidly northwards and westwards, due to the warming of the Mediterranean Sea [1].

Recently, a list of 51 Mediterranean fish species extended their distribution range to the northern Mediterranean has been published $[16,17]$. This has been confirmed by numerous findings of thermophilic species and species with subtropical affinity in the northernmost part of the Mediterranean, and the northern Adriatic Sea [18-21]. However, it was considered that these newly recorded thermophilic species, such as blue runner, Caranx crysos (Mitchill, 1815) [22], could not successfully form self-sustaining populations in the North Adriatic, and that they were expected to be seen mostly in warmer months of the year [23,24]. Nonetheless, it has been observed that predatory non-native fish species, for example, bluefish, Pomatomus saltatrix (Linnaeus, 1766), adapt well to conditions in new habitats and form large populations in the northernmost part of the Adriatic [25]. Similarly, the common dolphinfish, Coryphaena hippurus Linnaeus, 1758, became more common in the eastern part of the Adriatic Sea, and the presence of its juvenile stages has been recorded and confirmed [26,27].

The results of recent studies on the visual census of thermophilic fish species and species with sub-tropical affinity in the Bay of Medulin (North Adriatic, Istria) indicate the increased frequency of presence of the greater amberjack, Seriola dumerili (Risso, 1810) and the Mediterranean barracuda, Sphyraena sphyraena (Linnaeus, 1758); frequent occurrences of the leerfish, Lichia amia (Linnaeus, 1758); and incidences of the pompano, Trachinotus ovatus (Linnaeus, 1758) and P. saltatrix [28]. These species, indigenous in the Adriatic Sea, were not abundant in its southern part until about 20 years ago [17]. However, they have been unrecorded in scientific literature and unseen by local fishers (personal communication: Davor Iveša, Darko Kuzmanić). in the northern Adriatic.

Literature on the feeding habits of the aforementioned fish species from their indigenous habitat is abundant [29-33], but data on their dietary pattern in recently extended distributional range, in the eastern Adriatic Sea, are scarce. Thus, this study aims to investigate the feeding habits of the thermophilic C. crysos, C. hippurus, S. sphyraena and the species with subtropical affinity L. amia, P. saltatrix, S. dumerili, and T. ovatus caught in their newly extended habitat in the northeast Adriatic Sea, the Bay of Medulin. Specifically, the study examined the: (1) Main dietary items of prey available in the environment; (2) prey items of importance for each thermophile species and species with sub-tropical affinity; and (3) diet overlapping between investigated species. The period during which the largest number of individuals was caught, and the frequencies of their occurrence in the fishing catch, are also presented.

\section{Material and Methods}

\subsection{Study Area and Fish Sampling}

The study was conducted at three stations in the Bay of Medulin (Istria, Northern Adriatic): Dražice $\left(44^{\circ} 47^{\prime} 18.4^{\prime \prime} \mathrm{N} 13^{\circ} 54^{\prime} 54.1^{\prime \prime} \mathrm{E}\right)$, Školjić $\left(44^{\circ} 46^{\prime} 55.6^{\prime \prime} \mathrm{N} 13^{\circ} 55^{\prime} 08.1^{\prime \prime} \mathrm{E}\right)$ and Kažela $\left(44^{\circ} 48^{\prime} 06.7^{\prime \prime} \mathrm{N} 13^{\circ} 55^{\prime} 24.7^{\prime \prime}\right.$ E) (Figure 1). Unlike other parts of the coastal area in Istria, this area is specific for its diverse habitats and richness in nutrients [34]; http:/ / www.bioportal.hr/gis/, accessed on 15 October 2020). In the inner part of the bay, there are coastal lagoons, while the rest of the area is dominated by large shallow bays with diverse marine habitats, such as underwater reefs, caves and biocenoses of seagrass meadows [35]. There are 76 professional small-scale fishers, using gillnets as the main 
fishing gear, targeting fish in the wider area of the Bay of Medulin. They significantly contribute to the local commercial fishery.

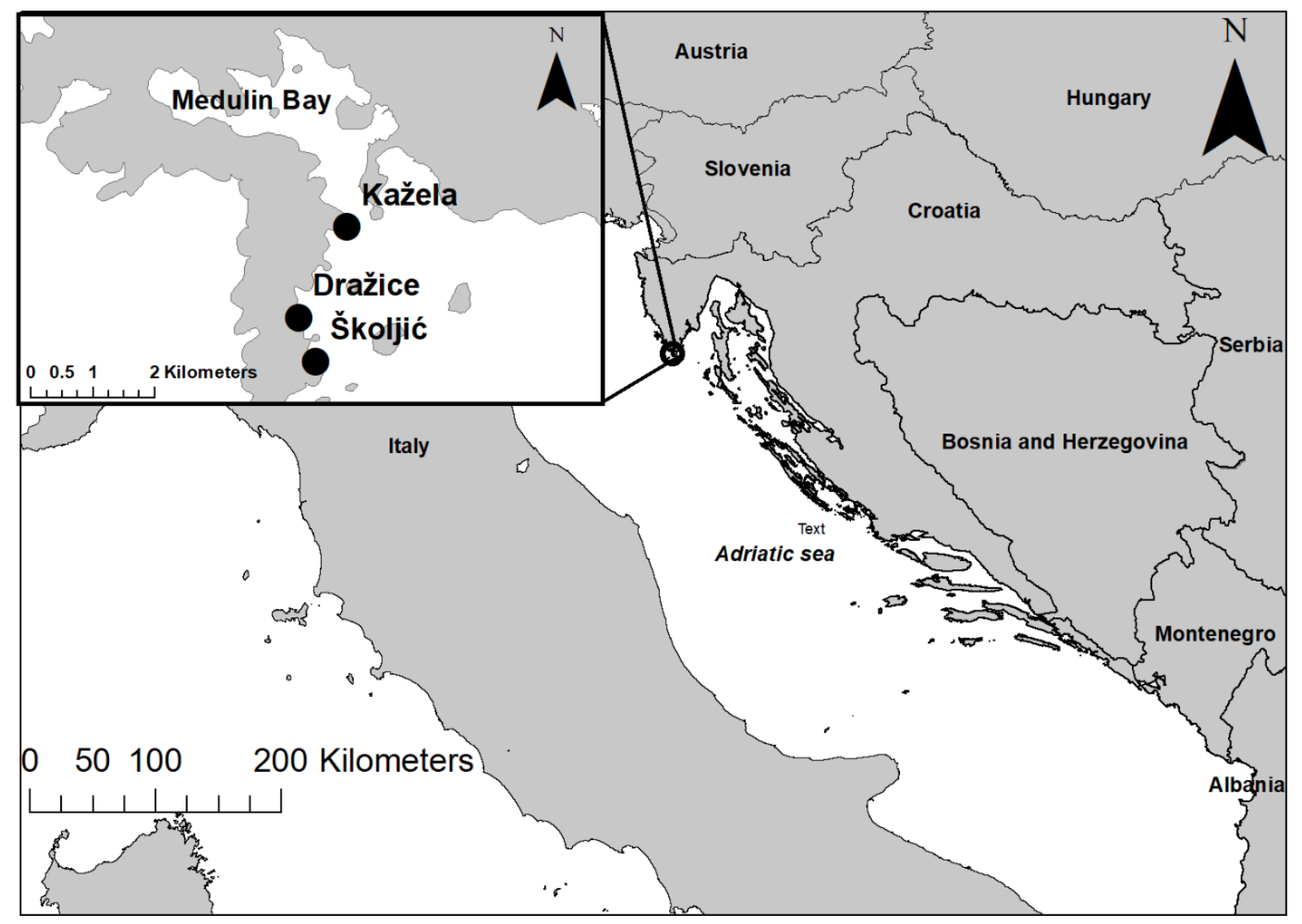

Figure 1. Sampling locations in the Bay of Medulin.

At each station, the collection of thermophilic fish and fish with subtropical affinity was conducted during regular fishing operations in the period from early summer (June) to early winter (February) during 2017 and 2018, and January 2019. After fish catches were analysed from these two years, additional samples were undertaken five times at each station, from August to October 2019. Gillnets were $8 \mathrm{~m}$ high with a mesh size of 32 or $40 \mathrm{~mm}$ made of polyamide filaments, $0.25 \mathrm{~mm}$ in diameter. The length of $40 \mathrm{~mm}$ mesh size gillnet was $140 \mathrm{~m}$, while the length of $32 \mathrm{~mm}$ mesh size gillnet was $120 \mathrm{~m}$. There were 52 deployments of the $40 \mathrm{~mm}$ mesh size gillnet performed simultaneously at each of three stations, making a total of 156 deployments. Only at station Dražice, a single gillnet of $32 \mathrm{~mm}$ mesh size was laid 18 times together with the deployment of the $40 \mathrm{~mm}$ mesh size gillnet.

The nets were deployed two to three times per month, from June until February, at each sampling site. Using the entanglement method, gillnets were laid close to the coast, attempting to deploy as close as possible to the seashore, and extended horizontally towards the sea. The last fifty meters were set in a semicircular manner to increase fish catchability. From the beginning to the end of the gillnets, the sea depth ranged from 1.5 to $12 \mathrm{~m}$. The start and end of each gillnet net were marked by a buoy. Gillnets were deployed around one hour before sunset and retrieved the next morning within one hour following sunrise. For deployment and hauling, a $5.95 \mathrm{~m}$ wooden fishing boat, with an 8 horsepower outboard engine was used. A hydraulic winch was used to haul the gillnets via a $4 \mathrm{KW}$ Honda power aggregate.

Additionally, a coastal purse seine was used to catch smaller specimens. The coastal purse seine was of $9 \mathrm{~mm}$ mesh size (three polyamide threads), $30 \mathrm{~m}$ long and $6 \mathrm{~m}$ high. It 
was deployed four times in 2019 at two sites (three hauls at Dražice station at the end of August, and one at the beginning of September at Školjić station) during daylight hours. When thermophilic fish or fish with sub-tropical affinity were detected and confirmed by visual observations using snorkelling equipment, this determined the location of its deployment.

\subsection{Gut Content Analysis, Diet Overlap and Prey Importance}

Sampled specimens were frozen immediately after capture to preserve the gut contents. After thawing, the total length ( $\mathrm{TL}$, in $\mathrm{cm}$ ) and weight (W, in g), mouth height $(\mathrm{MH}$, in $\mathrm{cm}$ ) and width (MW, in $\mathrm{cm}$ ) were measured. The number of gill rakers was counted on the first branchial arch at the right side. After measurements, each specimen was dissected, the entire content of the gut (stomach and the anterior third of the intestine) was removed, weighed and fixed in $96 \%$ ethanol. Recognisable organisms were subsequently identified to the family or genus level, when possible.

Assessment of the fish diet was based on the frequency of occurrence $(F \%)$, numerical frequency $(N \%)$ and mass frequency $(W \%)$ of the different diet components [36], using the following formulas:

$$
F \%=\frac{f_{i}}{\sum f} \times 100
$$

where $f_{i}$ is a number of guts containing each prey item and $\Sigma f$ is the total number of guts with food;

$$
N \%=\frac{n_{i}}{\sum f n} \times 100
$$

where $n_{i}$ is the total number of a particular prey item and $\Sigma n$ is the total number of prey items consumed by the fish;

$$
W \%=\frac{w_{i}}{\sum w} \times 100
$$

where $w_{i}$ is the total mass of a single prey item and $\Sigma w$ is the total mass of prey items consumed by the fish.

The analysis of changes in feeding habits was performed using the following indices [36]:

$$
\begin{aligned}
\text { Fulness index }(F I \%) & =\frac{\text { Total gut content weight }}{\text { Fish weight }} \times 100 \\
\text { Vacuity coefficient }(V I \%) & =\frac{\text { Number of empty guts }}{\text { Total number of guts analysed }} \times 100
\end{aligned}
$$

The index of absolute (IAI $\alpha)$ and relative importance IRI was calculated for each prey category.

$$
\begin{aligned}
& I A I \alpha=F \%+N \%+W \% \\
& I R I=100 \times \frac{I A I \alpha}{\sum_{\alpha=1}^{n} I A I \alpha}
\end{aligned}
$$

where: $\alpha$-specific prey category

$n$-number of different prey categories

Diet overlap was calculated using the index proposed by [37] based on IRI:

$$
\alpha=1-0.5\left(\sum_{i=1}^{n}\left|P V_{x i}-P V_{y i}\right|\right)
$$

where $n=$ number of prey items $P V_{x i}=$ percentage of prey item $i$ in species $x$ and $P V_{y i}=$ percentage of prey item $i$ in species $y$. Values range from 0 (no feeding overlap) to 1 (total feeding overlap), and values $>0.60$ represent significance. 


\subsection{Statistical Analysis of the Fish Feeding Habits}

Constrained Canonical Correspondence Analysis (CCA) with response data log transformations, both above test and unrestricted permutations were implemented in CANOCO v.5 software package [38] to analyse the importance of identified prey items based on mass frequency (response variables) in the diet of L. amia, S. dumerili and S. sphyraena, caught at different sampling sites (explanatory variables). To test importance in prey selectivity, mouth size, number of gill rakers and specimen size classes ( $<30$ and $>30 \mathrm{~cm}$ in TL) were used as explanatory variables. Explanatory variables, fish species and sampling sites, were expanded into dummy variables, and specimen size classes were presented as factors. Fish species represented with less than 20 specimens, and specimens with empty guts or guts containing only detritus were excluded from CCA analysis.

\section{Results}

In 2017, 2018 and January 2019, out of 52 gillnet deployments, thermophilic species and species with sub-tropical affinity were caught 30 times. Most individuals were detected in the period from late summer to late autumn. In 2019, when targeted fishing was performed from August to October, species were caught all five times out of five gillnets deployments, and caught four times by coastal purse seine (Appendix A Table A1).

In total, three thermophilic species and four species with subtropical affinity (220 specimens) were captured and analysed: One specimen of $C$. crysos, six specimens of $C$. hippurus, thirty-three specimens of S. sphyraena, twenty-two specimens of L. amia, eight specimens of $P$. saltatrix, one hundred and forty-seven specimens of $S$. dumerili, and three specimens of T. ovatus. Specimen sizes lower than $25 \mathrm{~cm}$ were not possible to catch by gillnets, due to its mesh size, therefore purse seine nets were used. In this way, juveniles of $S$. sphyraena and T. ovatus were captured, as well as smaller sample sizes of $S$. dumerili. TL of captured specimens ranged between 7.85 and $66.8 \mathrm{~cm}$, and $\mathrm{W}$ from 4.01 to $2850.30 \mathrm{~g}$ (Table 1; Appendix A Table A1). Eighty-one specimens have been found with empty stomachs, or with stomachs containing only detritus, consisting of unrecognised particles of ingested food, micro and macro plastic, and metal particles.

One specimen of C. crysos $(F I \%=0.62, \mathrm{TL}=37.5 \mathrm{~cm} ; \mathrm{W}=628.0 \mathrm{~g})$ was caught at the Dražice location in November 2018. Only unrecognisable remains of a bony fish (Pisces) were found in its stomach. Occasionally C. hippurus, P. saltatrix and T. ovatus were found in gillnets during the sampling period, and two juvenile specimens of T. ovatus were caught by coastal purse seine net. The main food items for C. hippurus were European pilchard, Sardina pilchardus (Walbaum, 1792), from Clupeidae family, and cephalophod, common squid, Loligo vulgaris Lamarck, 1798. Pomatomus saltatrix consumed unidentified species of Sparidae family, and T. ovatus fed on crustaceans from the order Mysidacea (Table 1, Figure 2).

Important food items for L. amia, $S$ dumerili and $S$. sphyraena were represented by species from the genus Atherina, but each of these three species seems to consume different Atherina species. Beside Atherina, significant food items for L. amia are represented by fishes from Sparidae family, for S. sphyraena from Carangidae family (including Trachurus sp.) and for S. dumerili fish from Clupeidae and Muliidae family (Table 1, Figure 2). 


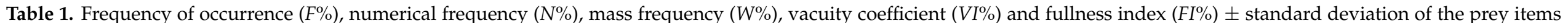

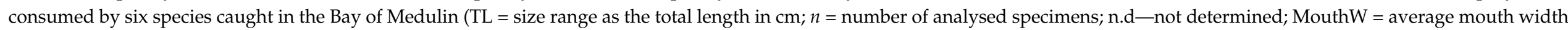
$(\mathrm{cm})$; MouthH = average mouth height $(\mathrm{cm})$; NoBraRig = mode of the number of rakers on the right gill arch).

\begin{tabular}{|c|c|c|c|c|c|c|c|c|c|c|c|c|c|c|c|c|c|c|c|}
\hline \multirow[t]{2}{*}{ Prey Item } & \multirow[t]{2}{*}{ 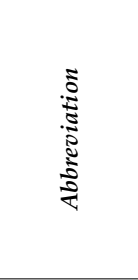 } & \multicolumn{3}{|c|}{$\begin{array}{c}\text { Coryphaena hippurus } \\
\mathrm{TL}=41.70-44.60 \\
F I \%=1.55 \pm 1.97 \\
V I \%=33.33 \\
\text { MouthW }=3.3 \\
\text { MouthH }=4.3 \\
\text { NoBraRig }=9 \\
n=6\end{array}$} & \multicolumn{3}{|c|}{$\begin{array}{c}\text { Lichia amia } \\
\text { TL = 24.00-66.80 } \\
F I \%=2.62 \pm 2.81 \\
V I \%=13.64 \\
\text { MouthW }=4.6 \\
\text { MouthH }=4.8 \\
\text { NoBraRig }=10 \\
n=22 \\
n=2\end{array}$} & \multicolumn{3}{|c|}{$\begin{array}{c}\text { Pomatomus saltatrix } \\
\mathrm{TL}=30.50-41.60 \\
F I \%=0.44 \pm 0.45 \\
V I \%=33.33 \\
\text { MouthW }=4.1 \\
\text { MouthH }=4.3 \\
\text { NoBraRig }=12 \\
n=8\end{array}$} & \multicolumn{3}{|c|}{$\begin{array}{c}\text { Seriola dumerili } \\
\mathrm{TL}=19.30-41.00 \\
F I \%=1.55 \pm 1.92 \\
V I \%=36.05 \\
\text { MouthW }=4.1 \\
\text { MouthH }=3.9 \\
\text { NoBraRig }=16 \\
n=147\end{array}$} & \multicolumn{3}{|c|}{$\begin{array}{c}\text { Sphyraena sphyraena } \\
\mathrm{TL}=13.40-38.60 \\
F I \%=1.38 \pm 1.89 \\
V I \%=54.55 \\
\text { MouthW }=1.6 \\
\text { MouthH }=2.9 \\
\text { NoBraRig }=0 \\
n=33\end{array}$} & \multicolumn{3}{|c|}{$\begin{array}{c}\text { Trachinotus ovatus } \\
\text { TL }=7.85-66.80 \\
F I \%=2.50 \pm 0.94 \\
V I \%=33.33 \\
\text { MouthW }=1.2 \\
\text { MouthH }=1.5 \\
\text { NoBraRig }=36 \\
n=3 \\
\end{array}$} \\
\hline & & $\mathrm{N} \%$ & $F \%$ & $W \%$ & $N \%$ & $F \%$ & $W \%$ & $\mathrm{~N} \%$ & $F \%$ & $W \%$ & $N \%$ & $F \%$ & $W \%$ & $\mathrm{~N} \%$ & $F \%$ & $W \%$ & $N \%$ & $F \%$ & $W \%$ \\
\hline Oblada melanura & OblMel & & & & 0.89 & 2.33 & 11.37 & & & & & & & & & & & & \\
\hline Pagellus erythrinus & PagEry & & & & & & & & & & 1.94 & 3.14 & 6.61 & & & & & & \\
\hline Sparidae n.d. & SparidND & & & & 8.04 & 11.63 & 5.59 & 14.29 & 20.00 & 64.91 & 7.44 & 8.90 & 8.34 & & & & & & \\
\hline Sardina pilchardus & SardPilc & 50.00 & 50.00 & 94.55 & & & & & & & 1.62 & 1.57 & 7.67 & & & & & & \\
\hline Clupeidae n.d & ClupeiND & & & & & & & & & & 10.68 & 9.95 & 9.31 & 5.00 & 5.26 & 5.21 & & & \\
\hline Atherina hepsetus & AtherHep & & & & 44.64 & 23.26 & 39.87 & & & & 10.36 & 9.95 & 6.52 & & & & & & \\
\hline Atherina boyeri & AtherBoy & & & & 8.04 & 9.30 & 3.87 & & & & 11.65 & 8.38 & 3.73 & 15.00 & 15.79 & 3.72 & & & \\
\hline Atherina sp. & AtherSp & & & & 24.11 & 18.60 & 23.10 & & & & 16.83 & 17.28 & 9.17 & 5.00 & 5.26 & 5.29 & & & \\
\hline Mullus barbatus & MullBarb & & & & & & & & & & 7.12 & 2.09 & 11.25 & & & & & & \\
\hline Belone belone & BelonBel & & & & 3.57 & 9.30 & 1.96 & & & & & & & & & & & & \\
\hline Sphyraena sp. & SphyraSp & & & & & & & & & & 0.65 & 1.05 & 0.74 & & & & & & \\
\hline Pisces n.d & PiscesND & & & & 8.04 & 13.95 & 13.11 & 71.43 & 60.00 & 31.19 & 19.09 & 21.47 & 9.75 & 55.00 & 52.63 & 10.80 & 0.08 & 33.33 & 0.15 \\
\hline Mysidiacea & Mysidiac & & & & & & & & & & 0.32 & 0.52 & 0.02 & & & & 99.52 & 33.34 & 96.79 \\
\hline Isopoda & Isopoda & & & & 1.79 & 4.65 & 0.07 & & & & 1.29 & 2.09 & 0.05 & 5.00 & 5.26 & 0.15 & & & \\
\hline Loligio vulgaris & LoliVulg & 50.00 & 50.00 & 5.45 & & & & & & & 1.29 & 2.09 & 9.89 & & & & & & \\
\hline Seppia officinalis & SepOffic & & & & & & & & & & 0.65 & 1.05 & 1.19 & & & & & & \\
\hline Cephalopoda n.d & CephalND & & & & & & & 14.29 & 20.00 & 3.90 & 1.62 & 2.62 & 2.42 & & & & & & \\
\hline Posidonia oceanica & PosidOce & & & & + & 2.33 & 0.03 & & & & & & & & & & & & \\
\hline Zoostera sp. & ZoosterS & & & & + & 2.33 & 0.01 & & & & + & 1.57 & 0.02 & & & & & & \\
\hline Hymenoptera n.d & - & & & & & & & & & & & & & & & & 0.40 & 33.33 & 3.05 \\
\hline
\end{tabular}




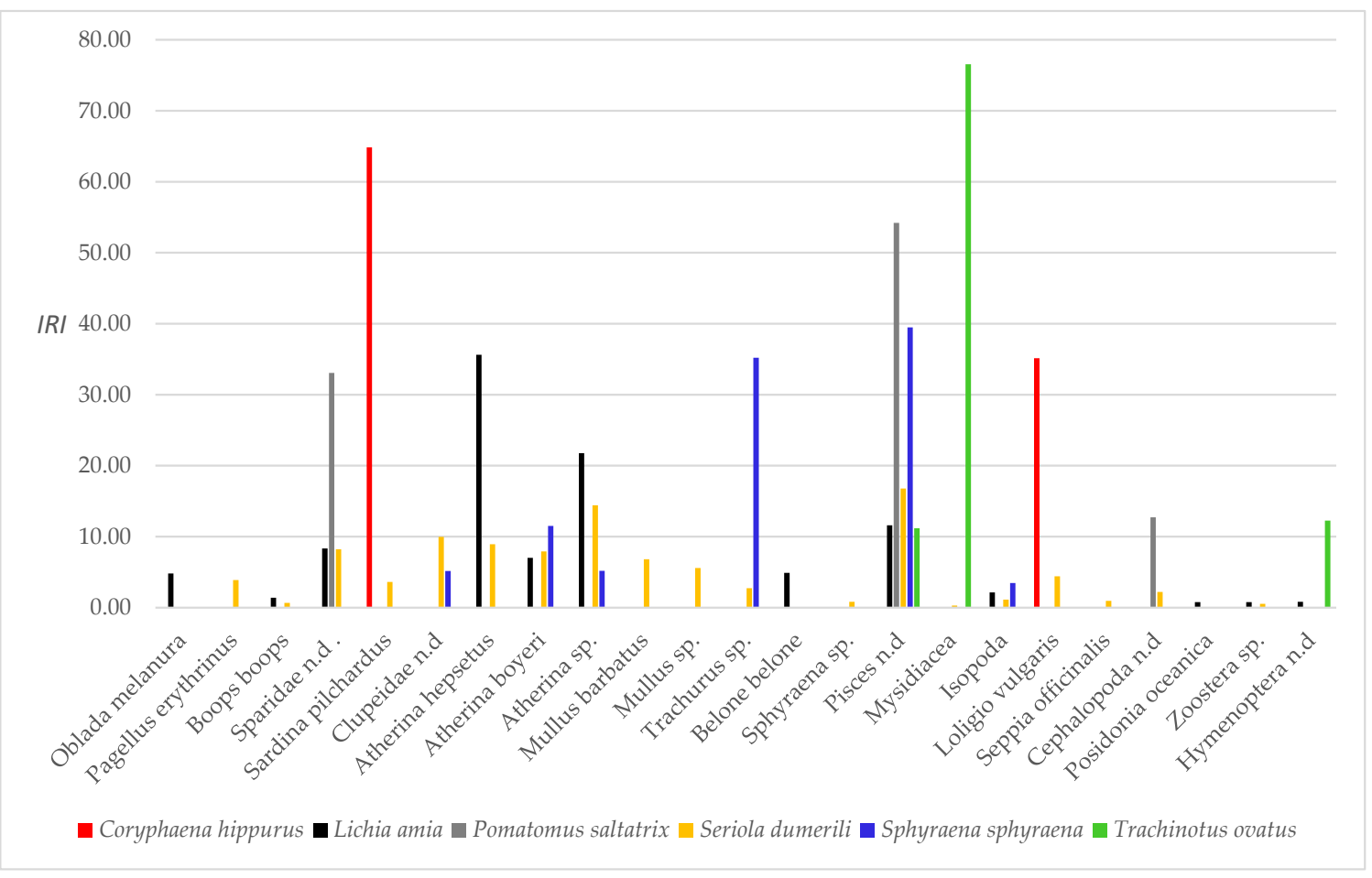

Figure 2. IRI prey importance for five fish species Coryphaena hippurus, Lichia amia, Pomatomus saltatrix, Seriola dumerili, Sphyraena sphyraena and Trachinotus ovatus caught in the Bay of Medulin.

Eigenvectors $(\lambda)$ of the CCA explained over $79 \%$ of the cumulative fitted variability on the first four axis $(\lambda 1=0.4859,40.93 \% ; \lambda 2=0.1979,67.60 \% ; \lambda 3=0.1615,71.21 \%$; $\lambda 4=0.1025,79.84 \%$ ). CCA analysis suggests that important food items of $L$. amia were garfish, Belone belone (Linnaeus, 1760), and different species of Atherina, a pelagic prey consumed at Kazela sampling station. At Školjić and Dražice sampling stations, S. dumerili consumed benthopelagic organisms, such as cephalopods, Mysidaceae crustaceans, common pandora, Pagellus erythrinus (Linnaeus, 1758), and demersal species represented by Mullus species. In the diet of $S$. sphyraena, the most important prey was represented by pelagic genus Trachurus from the family Carangidae. The number of gill rakers for S. dumerili, and mouth height and width for S. dumerili and L. amia, represent an important meristic trait in prey selectivity. Specimens $<30 \mathrm{~cm}$ in TL were related to Dražice sampling station, S. sphyraena feeding habits and Atherina sp. as prey items (Figure 3). Analysis of diet overlap based on IRI and $W \%$ proposed by Schoener, suggest no diet overlap between analysed species caught in Bay of Medulin (Table 2).

Table 2. Schoener index results based on IRI (underlined values) and mass frequency IRI (bold values) of feeding overlap of six thermophilic species caught in Bay of Medulin during 2017, 2018 and 2019.

\begin{tabular}{|c|c|c|c|c|c|c|}
\hline Species & $\begin{array}{c}\text { Coryphaena } \\
\text { hippurus }\end{array}$ & Lichia amia & $\begin{array}{l}\text { Pomatomus } \\
\text { saltatrix }\end{array}$ & $\begin{array}{c}\text { Seriola } \\
\text { dumerili }\end{array}$ & $\begin{array}{l}\text { Sphyraena } \\
\text { sphyraena }\end{array}$ & $\begin{array}{l}\text { Trachinotus } \\
\text { ovatus }\end{array}$ \\
\hline Coryphaena hippurus & - & $\underline{0.00}$ & $\underline{0.00}$ & $\underline{0.08}$ & $\underline{0.00}$ & $\underline{0.00}$ \\
\hline Lichia amia & 0.00 & - & $\underline{0.20}$ & $\underline{0.52}$ & $\underline{0.26}$ & $\underline{0.12}$ \\
\hline Pomatomus saltatrix & 0.00 & 0.19 & - & $\underline{0.27}$ & $\underline{0.39}$ & $\underline{0.11}$ \\
\hline Seriola dumerili & 0.13 & 0.36 & 0.21 & - & $\underline{0.40}$ & $\underline{0.11}$ \\
\hline Sphyraena sphyraena & 0.00 & 0.19 & 0.11 & 0.28 & - & $\underline{0.11}$ \\
\hline Trachinotus ovatus & 0.00 & 0.13 & 0.01 & 0.01 & 0.01 & - \\
\hline
\end{tabular}




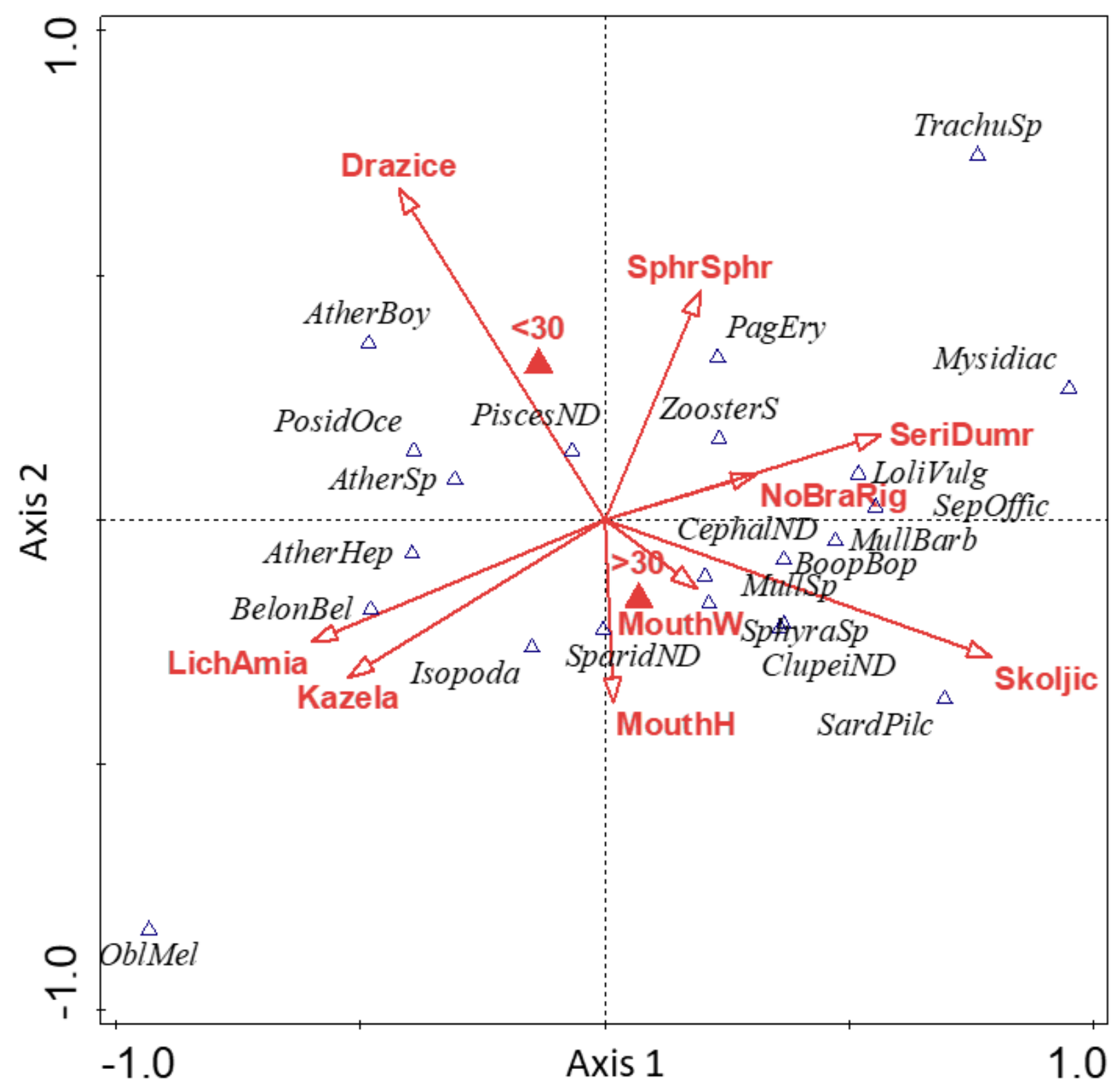

Figure 3. Canonical Correspondence Analysis (CCA) ordination diagram representing the mass percentage of main prey items consumed by three fish species (Lichia amia, Seriola dumerili, Sphyraena sphyraena) caught at each sampling site (Dražice, Kažela, Školjić) in the Bay of Medulin; Monte Carlo permutation test results on all axes: Pseudo-F $=2.0, p=0.002(\rightarrow$ explanatory variables, $\Delta$ — specimen size class, $\Delta$-prey item). See Table 1 and Appendix A Table A1 for abbreviations.

\section{Discussion}

The catch by gillnets for the purpose of this research suggest that adults of P. saltatrix and S. sphyraena inhabit the Bay of Medulin from June until February. Other species, $C$. crysos, C. hippurus, L. amia, S. dumerili and T. ovatus, were detected only from August until December.

The most numerous species with sub-tropical affinity caught in the Bay of Medulin was $S$. dumerili, whose diet was characterised by a large variety of prey items. The most important prey were benthopelagic cephalopods, crustaceans Mysidaceae, P. erythrinus and pelagic species of the genus Mullus. Indeed, its diet is dominated by smaller pelagic fish, which usually form schools (Trachurus, Sardina, Engraulis), bentho-pelagic fishes 
(Merlucius, Boops, Atherina) and benthic fish species (Gobius, Syngnathus, Hippocampus) [39]. Crayfish, bivalve molluscs and cephalopods were less common in its diet in other parts of the Mediterranean $[30,32,40,41]$. Prevalence of benthopelagic taxa (Sparidae, Atherina sp., Mullus sp.), detected by this research, may indicate opportunistic behaviour, i.e., targeted predation of species associated with seagrass habitats, typical for this area [42]. Apart from the genus Atherina, a significant component of the S. dumerili diet was red mullet, Mullus barbatus, Linnaeus, 1758, which spawns in the Adriatic from April to July [43], and whose recruits are available at the time when S. dumerili appears in the Bay of Medulin. In addition, the research has been conducted in shallow water (up to a maximum of $12 \mathrm{~m}$ ), which may allow cruise-chase predators to actively search the entire water column and select potentially available prey, especially in circumstances of high visibility. Furthermore, isopod crustaceans have been identified in the digestive tracts of S. dumerili, S. sphyraena and L. amia in this research. However, it seems that isopod crustaceans represent accidentally acquired prey. All three species consumed fishes from genus Atherina. The presence of isopods in their digestive system could be related to the infection of $A$. boyeri by the parasitic Isopoda, Mothocya epimerica Costa, 1851 in the Adriatic Sea [44].

Lichia amia is a top predator in shallow coastal areas. The diet of specimens from the Atlantic Ocean consists of pelagic and benthic prey, which usually form schools (Trachurus, Engraulis, Scomber, Argyrosomus, Umbrina, Pomadasys, Pagellus, Mugil, Atherina and Cheimerius) $[45,46]$. Similarly, in the Bay of Medulin, specimens of L. amia smaller than $30 \mathrm{~cm}$ in TL consumed Atherina sp. and bogue Boops boops (Linnaeus, 1758). Specimens larger than $30 \mathrm{~cm}$ in TL, beside Atherina sp. and saddled seabream Oblada melanura (Linnaeus, 1758), consumed epipelagic garfish Belone belone (Linnaeus, 1760), solitary predator which could be found mainly in offshore areas hunting crustaceans, and also schooling fishes [47]. Therefore, L. amia could compete for diet with B. belone and may affect its abundance in coastal areas of eastern Adriatic.

According to the literature [31,48], the European anchovy, Engraulis encrasicolus (Linnaeus, 1758), S. pilchardus, round sardinella, Sardinella aurita Valenciennes, 1847, B. boops and picarel Spicara smaris (Linnaeus, 1758) have been reported as the main diet of S. sphyraena, while crustaceans were represented by deep-water pink shrimp Parapenaeus longirostris (Lucas, 1846). Our results demonstrate that the primary prey for $S$. sphyraena was represented by Trachurus sp. and Atherina sp. In the north Adriatic, T. mediterraneus is the most common species of Trachurus. With spawning occurring during the spring and early summer [49,50], juveniles occur near the shore in late summer and early autumn [51], often in association with meroplanktonic scyphozoan jellyfishes, such as Cotylorhiza tuberculata (Macri, 1778), [52,53], or Rhizostoma pulmo (Macri, 1778), recently reported as abundant in the northern Adriatic [54]. Sphyraena sphyraena consumes small pelagic fish preys, that are in great abundance, and Atherina sp. was one of the most important prey for specimen sizes $<30 \mathrm{~cm}$ [55], which overlaps with results presented in this paper. Two species of atherinids are abundant in the Adriatic: Big-scale sand smelt, Atherina boyeri Risso, 1810, and Mediterranean sand smelt, Atherina hepstetus Linnaeus, 1758. Both fish species are gregarious, with the affinity to inhabit lagoons and estuaries. Atherina boyeri numerically dominate along the eastern Adriatic coast [56,57], and large shallow bays and coastal lagoons, such as Medulin Bay, providing favourable habitat conditions and making them available to incoming predators. Similarly, L. amia also consumed Atherina sp., which represents a prey of great abundance in the Bay of Medulin. However, our results suggesting that $S$. sphyraena prefers $A$. boyeri, while $L$. amia preferably consumes $A$. hepstetus, with no diet overlap existing between them. Nevertheless, such different prey consumption suggests that these species compete with some commercially important ones, such as European seabass, Dicentrarchus labrax (Linnaeus, 1758) or common dentex, Dentex dentex (Linnaeus, 1758) [58,59]. The natural diet of larger specimens $(\approx 30 \mathrm{~cm}$ in TL) of D. labrax consists mainly of $A$. boyeri and mugilids (Mugilidae) fry and juveniles [58], which seems overlapping with the feeding habits of S. sphyraena and L. amia, as well as S. dumerili. Similarly, the main food of D. dentex is represented by Trachurus sp. and S. pilchardus following 
by Penaeus kerathurus (Forskål, 1775), S. officinalis, L. vulgaris and Mediterranean tapeweed Posidonia oceanica (Linnaeus) Delile, 1813 [59]. The main food items of $D$. dentex coincides with the main food items found in the diet of S. sphyraena and L. amia, as well as S. dumerili from the Medulin Bay.

The first record of C. crysos in the Bay of Medulin confirms two previous findings of this species in the northeast Adriatic, suggesting that global warming may play an important role in its extended migration routes and the possibility of its establishment in the near future [22,60]. In addition to climate change, other factors, such as anthropogenic activities, have facilitated the northward movement of this species [61]. According to the comparison with the published data $[22,24,60,62,63]$, it is the largest reported specimen found in the Adriatic Sea, and it is among the largest recorded individuals of this species in the Mediterranean. Only one adult C. crysos was captured, its stomach content consisting only of remains of fish (Pisces). To some extent, this coincides with previously published data that this species is opportunistically predatory, consuming mainly pelagic fishes in combination with crustaceans, molluscs and cephalopods in lower proportion [47,64].

Occurrences of $C$. hippurus in the northern Adriatic could be explained by the presence of floating marine anthropogenic debris in large densities along the Adriatic coast $[65,66]$, caused by the natural movement of the Gulf Stream from the Strait of Otranto along the eastern Adriatic, and back along the Italian coast [67]. Coryphaena hippurus has been observed in the vicinity of floating objects, and such phenomena could contribute to its spreading to the northern Adriatic, to habitats rich in prey [68]. This species is epipelagic, and also opportunistically predatory, feeding on almost all forms of fish and zooplankton, as well as crustaceans and squids [69]. Results of this research reveal S. pilchardus as primary, and L. vulgaris as complementary prey for C. hippurus found in the Bay of Medulin. This suggests that $C$. hippurus is likely a threat to native $D$. dentex, given that its primary prey represents $S$. pilchardus following by L. vulgaris [59]. Moreover, C. hippurus feeding habits may overlap with Atlantic bonito, Sarda sarda (Bloch, 1793), another common native species in Medulin Bay, whose primary prey are S. aurita, S. pilchardus and the E. encrasicolus [70]. Specimens of $C$. hippurus were found in the shallow part of the Bay of Medulin, which may indicate its migration to shallow water in search of prey. Indeed, C. hippurus was recorded in mid-October when L. vulgaris migrates to shallow water [71], and S. pilchardus prepares for spawning in productive bays along the Adriatic coast [72].

In contrast to C. hippurus, the diet of T. ovatus consists of pelagic crustaceans and fishes, with the important contribution of molluscs, occasionally cnidarians, benthic foraminiferans and annelids, with a small fraction of insects, without any dominant prey, which characterises generalist feeders [33,73]. In the Bay of Medulin, T. ovatus consumed similar food items with the highest relative proportion of pelagic crustaceans from the order Mysidaceae. For the Adriatic Sea, T. ovatus was recorded as a vagrant, but in the late 1990s, for the first time, its fingerlings were found in southeast regions [74], and thereafter this species formed self-sustaining populations [73]. It seems to be migrating northwards, probably due to increased salinity and water temperatures $[67,75]$.

Only eight specimens of P. saltatrix were recorded in this study, caught only in gillnets, although this species is more abundant in the area [28], as in other parts of the Mediterranean and Adriatic [76-78]. Due to the low number of specimens caught in the Bay of Medulin, and because food was partly digested, it was not possible to identify to the species level the food items found in the stomach. It was possible to conclude that the diet consisted mostly of undetermined Sparidae species and other fish, and of cephalopods in a lower amount. This species is difficult to capture in regular nets because it is known to destroy the gear and result in fish escapes through torn pens $[79,80]$. Pomatomus saltatrix is an agressive predatory fish, which feeds predominantly on pelagic species of Atherinidae and Engraulidae [29], S. aurita, Mediterranean horse mackerel, Trachurus mediterraneus (Steindachner, 1868) and demersal species, such as comber Serranus cabrilla (Linnaeus, 1758) and surmullet Mullus surmuletus, Linnaeus, 1758 [80] in the Mediterranean Sea. [81] 
suggested that their far northern feeding migrations are interconnected with shoals of Mullus sp., which are the main fish group in many coves around the Istrian peninsula.

Although all investigated species are widening their distribution range, our results suggest no existence of diet overlap between them. However, it seems that their feeding strategies may affect local indigenous species, particularly those of commercial value, such as D. labrax or D. dentex [82]. The investigation was done on a limited number of caught specimens, probably because most of the described species are still establishing their populations in the newly extended area. Moreover, juveniles were underrepresented, hence it was not possible to perform a detailed analysis of size-dependent feeding habits and ontogenetic dietary shift.

Fish diversity estimates of the Mediterranean and the Adriatic have been changed, new species are described or reclassified, and depletion of indigenous top predators in the basin has been noted [1]. The northern Adriatic is facing an increase in seawater temperature and major changes in mechanisms and trophic structures that have facilitated the spread of thermophilic species [67]. However, by expanding the range of thermophilic ichthyofauna and species with sub-tropical affinity to the northern Adriatic, as in the case of the Bay of Medulin where these species are still not sufficiently valued by the marketplace, the potential for the seasonal trophic exploitation of new sources could be recognised [83], particularly due to the depletion of local commercially important targeted species [84]. Finally, from this research, we can conclude that the occurrence of thermophilic fish species and species with sub-tropical affinity has become commonplace during the warmer months of the year in the northern Adriatic, with the possibility that they have found their own trophic niche in the area. However, the impact of this occurrence on the entire community remains unknown, and future research should be focused on this issue.

Author Contributions: All authors contributed extensively to the work presented in this paper. A.G. and M.P. designed the study. N.I., M.G., A.G. and T.T. collected the data. N.I., I.Š., T.R. and K.K. analysed and interpreted the results. N.I. and M.P. prepared the manuscript. A.G., J.J.-D. and T.T. finalised the article. All authors have read and agreed to the published version of the manuscript.

Funding: The authors did not receive support from any organisation for the submitted work.

Institutional Review Board Statement: Not applicable.

Informed Consent Statement: Not applicable.

Data Availability Statement: The data presented in this study are available on request from the corresponding author. The data are not publicly available because no valid data repositories exist.

Acknowledgments: We would like to thank the anonymous reviewers for their constructive comments that greatly improved the manuscript.

Conflicts of Interest: The authors declare no conflict of interest. 


\section{Appendix A}

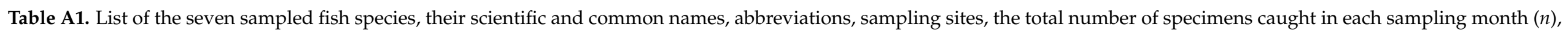
minimal ( $\mathrm{min}$ ) and maximal (max) total length and weight, and type of net used from 2017-2019 from the Medulin bay, Istria ( $G=$ gillnet; $S=$ coastal purse seine net).

\begin{tabular}{|c|c|c|c|c|c|c|c|c|c|c|c|c|c|c|c|c|c|c|c|c|}
\hline \multirow{4}{*}{ Scientific Name and Authority } & \multirow{4}{*}{$\begin{array}{l}\text { Common } \\
\text { Name }\end{array}$} & \multirow{4}{*}{ 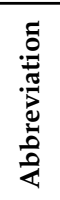 } & \multirow{4}{*}{ Year } & \multirow{4}{*}{$\begin{array}{l}\text { Sampling } \\
\text { Month }\end{array}$} & \multicolumn{16}{|c|}{ Sampling Site } \\
\hline & & & & & \multirow{3}{*}{$\begin{array}{c}\text { Type } \\
\text { of Net }\end{array}$} & \multicolumn{5}{|c|}{ Dražice } & \multicolumn{5}{|c|}{ Školjić } & \multicolumn{5}{|c|}{ Kažela } \\
\hline & & & & & & \multirow{2}{*}{$n$} & \multicolumn{2}{|c|}{ TL (cm) } & \multicolumn{2}{|c|}{ W (g) } & \multirow{2}{*}{$n$} & \multicolumn{2}{|c|}{ TL (cm) } & \multicolumn{2}{|c|}{ W (g) } & \multirow[t]{2}{*}{$n$} & \multicolumn{2}{|c|}{ TL (cm) } & \multicolumn{2}{|c|}{ W (g) } \\
\hline & & & & & & & Min & $\operatorname{Max}$ & Min & $\operatorname{Max}$ & & Min & Max & Min & Max & & Min & Max & Min & Max \\
\hline \multirow{9}{*}{ Seriola dumerili (Risso, 1810) } & \multirow{9}{*}{$\begin{array}{c}\text { Greater } \\
\text { amberjack }\end{array}$} & \multirow{9}{*}{ 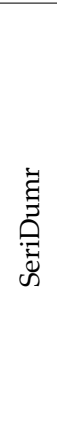 } & \multirow{3}{*}{2017} & 9 & G & 2 & 26.0 & 27.2 & 213.7 & 238.1 & & & & & & & & & & \\
\hline & & & & 10 & G & 7 & 22.9 & 35.1 & 129.6 & 539.0 & 15 & 29.5 & 36.7 & 319.9 & 626.3 & & & & & \\
\hline & & & & 11 & G & 2 & 28.7 & 31.8 & 285.8 & 402.0 & 3 & 33.1 & 36.4 & 331.9 & 661.4 & & & & & \\
\hline & & & \multirow{3}{*}{2018} & 9 & G & 7 & 19.7 & 32.7 & 94.1 & 392.2 & & & & & & & & & & \\
\hline & & & & 10 & G & 2 & 27.9 & 32.1 & 314.4 & 377.7 & 7 & 29.9 & 34.7 & 298.9 & 568.8 & 7 & 34.7 & 41.0 & 458.2 & 774.0 \\
\hline & & & & 11 & G & & & & & & 5 & 32.4 & 40.6 & 352.5 & 836.8 & & & & & \\
\hline & & & \multirow{3}{*}{2019} & 8 & S & 9 & 19.5 & 23.2 & 70.1 & 152.4 & & & & & & & & & & \\
\hline & & & & 9 & G, S & 5 & 24.3 & 29.4 & 168.1 & 319.3 & 24 & 19.3 & 31.3 & 99.6 & 348.2 & & & & & \\
\hline & & & & 10 & G & 4 & 31.7 & 35.8 & 352.1 & 538.4 & 18 & 26.1 & 39.9 & 194.9 & 662.1 & 30 & 30.1 & 38.3 & 322.3 & 651.3 \\
\hline \multirow{6}{*}{ Pomatomus saltatrix (Linnaeus, 1766) } & & & & 6 & G & 1 & & & 35 & & & & & & & & & & & \\
\hline & & & & 10 & G & & & & & & & & & & & & & & & \\
\hline & Bluefish & ' & & 12 & G & 1 & & & 49 & & & & & & & & & & & \\
\hline & & & 2018 & 11 & G & & & & & & 1 & & & 66 & & & & & & \\
\hline & & & & 1 & G & 1 & & & 22 & & & & & & & & & & & \\
\hline & & & 2019 & 10 & G & & & & & & & & & & & 1 & & & & \\
\hline & & & & 2 & G & & & & & & 1 & & & 21 & & & & & & \\
\hline & & & 2018 & 6 & G & 2 & 35.7 & 35.9 & 190.9 & 194.3 & & & & & & & & & & \\
\hline Sphyraena sphyraena (Linnaeus, 1758) & Mediterranean & क्टे & & 11 & G & 8 & 31.5 & 38.3 & 142.6 & 236.7 & & & & & & & & & & \\
\hline & & के & & 8 & $\mathrm{G}, \mathrm{S}$ & 21 & 13.4 & 35.3 & 8.3 & 150.4 & & & & & & & & & & \\
\hline & & & 2019 & 9 & G & 1 & & & 16 & & & & & & & & & & & \\
\hline
\end{tabular}


Table A1. Cont.

\begin{tabular}{|c|c|c|c|c|c|c|c|c|c|c|c|c|c|c|c|c|c|c|c|c|}
\hline \multirow{4}{*}{ Scientific Name and Authority } & \multirow{4}{*}{$\begin{array}{l}\text { Common } \\
\text { Name }\end{array}$} & \multirow{4}{*}{ 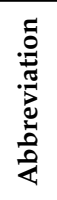 } & \multirow{4}{*}{ Year } & \multirow{4}{*}{$\begin{array}{l}\text { Sampling } \\
\text { Month }\end{array}$} & \multicolumn{16}{|c|}{ Sampling Site } \\
\hline & & & & & \multirow{3}{*}{$\begin{array}{l}\text { Type } \\
\text { of Net }\end{array}$} & \multicolumn{5}{|c|}{ Dražice } & \multicolumn{5}{|c|}{ Školjić } & \multicolumn{5}{|c|}{ Kažela } \\
\hline & & & & & & \multirow{2}{*}{$n$} & \multicolumn{2}{|c|}{ TL (cm) } & \multicolumn{2}{|c|}{ W (g) } & \multirow{2}{*}{$n$} & \multicolumn{2}{|c|}{$\mathrm{TL}(\mathrm{cm})$} & \multicolumn{2}{|c|}{ W (g) } & \multirow{2}{*}{$n$} & \multicolumn{2}{|c|}{ TL (cm) } & \multicolumn{2}{|c|}{ W (g) } \\
\hline & & & & & & & Min & Max & Min & Max & & Min & Max & Min & Max & & Min & Max & Min & Max \\
\hline \multirow{6}{*}{ Lichia amia (Linnaeus, 1758) } & \multirow{6}{*}{ Leerfish } & \multirow{6}{*}{ 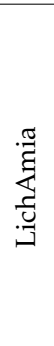 } & 2017 & 10 & G & & & & & & 2 & 27.9 & 34.9 & 253.8 & 359.8 & 2 & 31.6 & 36.1 & 213.1 & 447.0 \\
\hline & & & \multirow[b]{2}{*}{2018} & 10 & G & & & & & & & & & & & 9 & 35.2 & 44.9 & 432.4 & 830.0 \\
\hline & & & & 11 & G & & & & & & & & & & & 4 & 37.8 & 41.3 & 476.6 & 672.5 \\
\hline & & & \multirow{3}{*}{2019} & 8 & $\mathrm{~S}$ & 2 & 24.0 & 26.9 & 124.5 & 174.0 & & & & & & & & & & \\
\hline & & & & 9 & $\mathrm{~S}$ & & & & & & 1 & \multicolumn{2}{|c|}{21.3} & \multicolumn{2}{|c|}{28.0} & & & & & \\
\hline & & & & 10 & G & & & & & & & & & & & 1 & \multicolumn{2}{|c|}{34.2} & \multicolumn{2}{|c|}{338.0} \\
\hline Coryphaena hippurus Linnaeus, 1758 & $\begin{array}{l}\text { Common } \\
\text { dolphinfish }\end{array}$ & ' & 2017 & 10 & G & & & & & & & & & & & 6 & 41.7 & 44.6 & 392.2 & 512.2 \\
\hline Caranx crysos (Mitchill, 1815) & Blue runner & ' & 2018 & 11 & G & 1 & & & & & & & & & & & & & & \\
\hline Trachinotus ovatus (Linnaeus, 1758) & Pomnan & 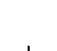 & 2018 & 8 & $\mathrm{~S}$ & 2 & 7.8 & 8.4 & 4.0 & 5.5 & & & & & & & & & & \\
\hline
\end{tabular}




\section{References}

1. Coll, M.; Piroddi, C.; Steenbeek, J.; Kaschner, K.; Lasram, F.B.R.; Aguzzi, J.; Ballesteros, E.; Bianchi, C.N.; Corbera, J.; Dailiantis, T.; et al. The biodiversity of the Mediterranean Sea: Estimates, patterns and threats. PLoS ONE 2010, 5, e11842. [CrossRef]

2. Katsanevakis, S.; Coll, M.; Piroddi, C.; Steenbeek, J.; Lasram, F.B.R.; Zenetos, A.; Cardoso, A.C. Invading the Mediterranean Sea: Biodiversity patterns shaped by human activities. Front. Mar. Sci. 2014, 1, 32. [CrossRef]

3. Lejeusne, C.; Chevaldonné, P.; Pergent-Martini, C.; Boudouresque, C.F.; Pérez, T. Climate change effects on a miniature ocean: The highly diverse, highly impacted Mediterranean Sea. Trends Ecol. Evol. 2010, 25, 250-260. [CrossRef] [PubMed]

4. Gambaiani, D.D.; Mayol, P.; Isaac, S.J.; Simmonds, M.P. Potential impacts of climate change and greenhouse gas emissions on Mediterranean marine ecosystems and cetaceans. J. Mar. Biol. Assoc. U.K. 2009, 89, 179-201. [CrossRef]

5. Fredj, G. Stockage et exploitation des données en écologie marine. A-un fichier sur ordinateur des invertebres macrobenthiques. Mem. De L'institut Oceanogr. (Monaco) 1974, 4, 1-61.

6. Calvo, E.; Simó, R.; Coma, R.; Ribes, M.; Pascual, J.; Sabbatés, A.; Gili, J.M.; Pelejero, C. Effects of climate change on Mediterranean marine ecosystems: The case of the Catalan Sea. Clim. Res. 2011, 50, 1-29. [CrossRef]

7. Salat, J. Review of hydrographic environmental factors that may influence anchovy habitats in the northwestern Mediterranean. Sci. Mar. 1996, 60, 21-32.

8. Bianchi, C.N.; Morri, C. Global sea warming and "tropicalisation" of the Mediterranean Sea: Situation, problems and prospects for future research. Mar. Pollut. Bull. 2000, 40, 367-376. [CrossRef]

9. Francour, P.; Boudouresque, C.F.; Harmelin, J.G.; Harmelin-Vivien, M.L.; Quingard, J.P. Are the Mediterranean waters becoming warmer? Information from biological indicators. Mar. Pollut. Bull. 1994, 28, 523-526. [CrossRef]

10. Morri, C.; Bianchi, C.N. Recent Changes in Biodiversity in the Ligurian Sea (NW Mediterranean): Is there a Climatic Forcing? In Mediterranean Ecosystems; Faranda, F.M., Guglielmo, L., Spezie, G., Eds.; Springer: Milano, Italy, 2001; pp. 375-384. [CrossRef]

11. Stebbing, A.R.D.; Turk, S.M.T.; Wheeler, A.; Clarke, K.R. Immigration of southern fish species to south-west England linked to warming of the North Atlantic (1960-2001). J. Mar. Biol. Assoc. U.K. 2002, 82, 177-180. [CrossRef]

12. Bodilis, P.; Crocetta, F.; Langeneck, J.; Francour, P. The spread of an Atlantic fish species, Pomadasys incisus (Bowdich, 1825) (Osteichtyes: Haemulidae), within the Mediterranean sea with new additional records from the French Mediterranean coast. Ital. J. Zool. 2013, 80, 273-278. [CrossRef]

13. Ricciardi, A. Assessing species invasions as a cause of extinction. Trends Ecol. Evol. 2004, 19, 619. [CrossRef]

14. Galil, B.S. Loss or gain? Invasive aliens and biodiversity in the Mediterranean Sea. Mar. Pollut. Bull. 2007, 55, 314-322. [CrossRef] [PubMed]

15. Galil, B.S. Seeing Red: Alien species along the Mediterranean coast of Israel. Aquat. Invasions. 2007, 2, 281-312. [CrossRef]

16. Azzurro, E. The advance of thermophilic fish in the Mediterranean Sea: Overview and methodological questions U. In Climate Warming and Related Changes in Mediterranean Marine Biota, CIESM Workshop Monographs; Briand, F., Ed.; CIESM: Monaco City, Monaco, 2008; Volume 35, pp. 39-46.

17. Azzurro, E.; Sbragaglia, V.; Cerri, J.; Bariche, M.; Bolognini, L.; Souissi, J.B.; Busoni, G.; Coco, S.; Chryssanthi, A.; Garrabou, J.; et al. Climate change, biological invasions and shifting distribution of Mediterranean fishes: A large-scale survey based on ecological knowledge. Glob. Chang. Biol. 2019, 25, 2779-2792. [CrossRef]

18. Bettoso, N.; Dulčić, J. First record of the oilfish Ruvettus pretiosus (Pisces: Gempylidae) in the northern Adriatic Sea. J. Mar. Biol. Assoc. U.K. 1999, 79, 1145-1146. [CrossRef]

19. Parenti, P.; Bressi, N. First record of the orange-spotted grouper, Ephinephelus coioides (Perciformes: Serranidae) in the Northern Adriatic Sea. Cybium 2001, 25, 281-284.

20. Sinovčić, G.; Franičević, M.; Zorica, B.; Čikeš-Keč, V. Length-weight and length-length relationships for 10 pelagic fish species from the Adriatic Sea (Croatia). J. Appl. Ichthyol. 2004, 20, 156-158. [CrossRef]

21. Psomadakis, P.N.; Scacco, U.; Vacchi, M. Recent findings of some uncommon fishes from the central Tyrrhenian Sea. Cybium 2006, 30, 297-304.

22. Nerlović, V.; Mravinac, B.; Devescovi, M. Additional information on the blue runner, Caranx crysos (Mitill, 2013, 1815) from the Nothern Adriatic Sea: Meristic and molecular characterisations. Acta Adriat. 2015, 56, 309-318.

23. Bianchi, C.N. Biodiversity issues for the forthcoming tropical Mediterranean Sea. In Biodiversity in Enclosed Seas and Artificial Marine Habitats. Developments in Hydrobiology; Relini, G., Ryland, J., Eds.; Springer: Dordrecht, The Netherlands, 2007 ; Volume 193. [CrossRef]

24. Psomadakis, P.N.; Bentivegna, F.; Giustino, S.; Travaglini, A.; Vacchi, M. Northward spread of tropical affinity fishes: Caranx crysos (Teleostea: Carangidae), a case study from the Mediterranean Sea. Ital. J. Zool. 2011, 78, 113-123. [CrossRef]

25. Dulčić, J.; Dragičević, B.; Matić-Skoko, S.; Pavičić, M.; Vrdoljak, D. Bluefish Pomatomus saltatrix again in the fishing catches in the Noirthern Adriatic. In Proceedings of the Rapport Du 2019, 42e Congres De La CIESM/Frédéric Briand, Cascais, Portugal, 7-11 October 2019; p. 277.

26. Dulčić, J. First record of larval Brama brama (Pisces: Bramidae) and Coryphaena hippurus (Pisces: Coryphaenidae) in the Adriatic Sea. J. Plankton Res. 1999, 21, 1171-1174. [CrossRef]

27. Dragičević, B.; Dulčić, J.; Pallaoro, A.; Paladin, A.; Stagličić, N. First record of the dolphin-fish juveniles, Coryphaena hippurus (Linnaeus, 1758), in the eastern Adriatic Sea. Ann. Ser. Hist. Nat. 2010, 20, 157-160. 
28. Iveša, N.; Piria, M.; Gelli, M.; Mičić, M.; Gavrilović, A. Prisutnost i distribucija termofilnih vrsta riba u Medulinskom zaljevu. In Proceedings of the 2018, 53th Croatian \& 13th International Symposium on Agriculture, Vodice, Croatia, 18-23 February 2020; pp. 360-364.

29. Juanes, F.; Hare, J.A.; Miskiewicz, A.G. Comparing early life history strategies of Pomatomus saltatrix: A global approach. Mar. Freshw. Res. 1996, 47, 365-379. [CrossRef]

30. Andalaro, F.; Pipitone, C. Food and feeding habits of the amberjack, Seriola dumerili, in the Central Mediterranean Sea during the spawning season. Cah. Biol. Mar. 1997, 38, 91-96.

31. Aggrey-Fynn, J.; Fynn-Korsah, S.; Appiah, N. Length-weigth relationship and food preference of two costal marine fishes, Galeoides decadactylus (Polynemnidae) and Sphyraena sphyraena (Sphyrenidae) off Cape Coast, Ghana. West Afr. J. Appl. Ecol. 2013, 21, 81-96.

32. Sley, A.; Taieb, A.H.; Jarboui, O.; Ghorbel, M.; Bouain, A. Feeding behavior of greater amberjack Seriola dumerili (Risoo, 1810) from Central Mediterranean (Gulf of Gabes, Tunisia). J. Mar. Biol. Assoc. U. K. 2016, 96, 1229-1234. [CrossRef]

33. Battaglia, P.; Pedà, C.; Musolino, S.; Esposito, V.; Andaloro, F.; Romeo, T. Diet and first documented data on plastic ingestion of Trachinotus ovatus L. 1758 (Pisces: Carangidae) from the Strait of Messina (central Mediterranean Sea). Ital. J. Zool. 2016, 83, 121-129. [CrossRef]

34. Bakran-Petricioli, T.; Antonić, O.; Bukovec, D.; Petricioli, D.; Janeković, I.; Križan, J.; Kušan, V.; Dujmović, S. Modelling spatial distribution of the Croatian marine benthic habitats. Ecol. Modell. 2006, 191, 96-105. [CrossRef]

35. Bakran-Petricioli, T. Marine Habitats of the Region of Istria. Institute for Physical Planning Region of Istria. 2013. Available online: http://shape.istra-istria.hr/uploads/media/Morska_stanista_-_DVD_Book_ZA_TISAK_MPS_Konacno_Preview.pdf (accessed on 19 May 2020). (In Croatian)

36. Hyslop, E.J. Stomach contents analysis: A review of methods and their application. J. Fish Biol. 1980, 17, 411-429. [CrossRef]

37. Schoener, T.W. Non-synchronous spatial overlap of lizards in patchy enviroments. Ecology 1970, 51, 408-418. [CrossRef]

38. Ter Braak, C.J.F.; Šmilauer, P. Canoco Reference Manual and User's Guide: Software for Ordination, 5th ed.; Microcomputer Power: Ithaca, NY, USA, 2012; p. 496.

39. Matallanas, J.; Casadevall, M.; Carrassón, M.; Boix, J.; Fernández, V. The food of Seriola dumerili (Pisces: Carangidae) in the Catalan Sea (western Mediterranean). J. Mar. Biol. Assoc. U.K. 1995, 75, 257-260. [CrossRef]

40. Badalamenti, F.; D'Anna, G.; Lopiano, L.; Scilipoti, D.; Mazzola, A. Feeding habits of young-of-the-year greater amberjack Seriola dumerili (Risso, 1810) along the N/W Sicilian coast. Sci. Mar. 1995, 59, 317-323.

41. Garcia-Gomez, A. Recent advantages in nutritional aspects of Seriola dumerili. Cah. Options Méditerranées 2000, 47, $249-257$.

42. Bakran-Petricioli, T. Manual for Determination of Marine Habitats in Croatia According to EU Habitat Directive, Državni Zavod Za Zaštitu Prirode. 2011. Available online: http:/ / www.haop.hr/sites/default/files/uploads/publications/2018-01/BakranPetricioli\%20-\%20Prirucnik\%20za\%20morska\%20stanista.pdf (accessed on 18 May 2020). (In Croatian).

43. Carbonara, P.; Intini, S.; Modugno, E.; Maradonna, F.; Spedicato, M.T.; Lembo, G.; Zupa, W.; Carnevali, O. Reproductive biology characteristics of red mullet (Mullus barbatus L., 1758) in Southern Adriatic Sea and management implications. Aquat Living Resour 2015, 28, 21-31. [CrossRef]

44. Bello, G.; Vaglio, A.; Piscitelli, G. The reproductive cycle of Mothocya epimerica (Isopoda: Cymothoidae), a parasite of the sand smelt, Atherina boyeri (Osteichtyes: Atherinidae), in the Lesina Lagoon, Italy. J. Nat. Hist. 1997, 31, 1055-1066. [CrossRef]

45. Marais, J.F.K. Feeding ecology of mayor carnivorous fish from eastern Cape estuaries. S. Afr. Zool. 1984, 19, 210-223. [CrossRef]

46. Smale, M. The feeding habits of six pelagic and predatory teleosts in eastern Cape coastal waters (South Africa). J. Zool. 1986, 1, 357-409. [CrossRef]

47. Froese, R.; Pauly, D. Editors FishBase. World Wide Web Electronic Publication. Available online: www.fishbase.org (accessed on 15 December 2019).

48. Jardas, I. Hrvatska Ihtiofauna; Školska knjiga: Zagreb, Croatiapp, 1996; p. 535.

49. Karlou-Riga, C. Otolith morphology and age and growth of Trachurus mediterraneus (Steindachner) in the Eastern Mediterranean. Fish. Res. 2000, 46, 69-82. [CrossRef]

50. Raya, V.; Sabatés, A. Diversity and distribution of early life stages of carangid fishes in the northwestern Mediterranean: Responses to environmental drivers. Fish. Oceanogr. 2015, 24, 118-134. [CrossRef]

51. Viette, M.; Giulianini, P.G.; Ferrero, E.A. Reproductive biology of scad, Trachurus mediterraneus (Teleostei, Carangidae), from the Gulf of Trieste. ICES J. Mar. Sci. 1997, 54, 267-272. [CrossRef]

52. D'Ambra, I.; Malej, A. Scyphomedusae of the Mediteranean: State of the art and future perspectives. Cent. Nerv. Syst. Agents. Med. Chem. 2015, 15, 81-94. [CrossRef]

53. Tilves, U.; Sabatés, A.; Blázquez, M.; Raya, V.; Fuentes, V.L. Associations between fish and jellyfish in the NW Mediterranean. Mar. Biol. 2018, 165, 127. [CrossRef]

54. Ramšak, A.; Stopar, K.; Malej, A. Comparative phylogeography of meroplanktonic species, Aurelia spp. and Rhizostoma pulmo (Cnidaria: Scyphozoa) in European Seas. In Jellyfish Blooms IV. Developments in Hydrobiology; Purcell, J., Mianzan, H., Frost, J.R., Eds.; Springer: Dordrecht, The Netherlands, 2012; Volume 220, pp. 69-80. [CrossRef]

55. Allam, S.M.; Faltas, S.N.; Ragheb, E. Food and feeding habits of barracudas in the Egyptian Mediterranean waters of Alexandria. Bull. Nat. Inst. Oceanogr. Fish. ARE 1999, 25, 395-410. 
56. Glamuzina, B.; Pešić, A.; Joksimović, A.; Glamuzina, L.; Matić-Skoko, S.; Conides, A.; Klaoudatos, D.; Zacharaki, P. Observations on the increase of wild gilthead seabream, Sparus aurata abundance in the eastern Adriatic sea: Problems and opportunities. Int. Aquat. Res. 2014, 6, 127-134. [CrossRef]

57. Kruschel, C.; Schultz, S.T. Aggressive predation drives assembley of Adriatic fish communities. Diversity 2020, 12, 130. [CrossRef]

58. Rogdakis, Y.; Ramfos, A.; Koukou, K.; Dimitrou, E.; Katselis, G. Feeding habits and trophic level of sea bass (Dicentrarchus labrax) in the Messolonghi-Etoliko lagoons complex (Western Greece). J. Biol. Res. Thessal. 2010, 13, 13-26.

59. Marengo, M.; Durieux, E.D.H.; Marchand, B.; Francour, P. A review of biology, fisheries and population structure of Dentex dentex (Sparidae). Rev. Fish Biol. Fish. 2014, 24, 1065-1088. [CrossRef]

60. Dulčić, J.; Pallaoro, A.; Dragičević, B. First record of the blue runner, Caranx crysos (Mitchill, 1815), in the Adriatic Sea. J. Appl. Ichthyol. 2009, 25, 481-482. [CrossRef]

61. Sinopoli, M.; Lauria, V.; Garofalo, G.; Maggio, T.; Cillari, T. Extensive use of fish aggregating devices together with environmental change influenced the spatial distribution of a tropical affinity fish. Sci. Rep. 2019, 9, 4934. [CrossRef]

62. Dulčić, J.; Dragičević, B.; Antolović, N.; Sulić-Šprem, J.; Kožul, V.; Grgičević, R. Additional records of Lobotes surinamensis, Caranx crysos, Enchelicore anatina, Lagocephalus sceleratus (Actinopterygii) in the Adriatic sea. Acta Ichthyol. Piscat. 2014, 44, 71-74. [CrossRef]

63. Pavičić, M.; Šiljić, J.; Duganđžić, P.; Skaramuca, B. New records of blue runner, Caranx crysos (Mitchill, 1815) in the Adriatic Sea. Croat. J. Fish. 2014, 72, 125-127. [CrossRef]

64. Sley, A.; Jarboui, O.; Ghorbel, M.; Bouain, A. Food and feeding habits of Caranx crysos from the Goulf of Gabes (Tunisia). J. Mar. Biol. Assoc. U. K. 2009, 89, 1375-1380. [CrossRef]

65. Sinopoli, M.; Castriota, L.; Vivona, P.; Gristina, M.; Andaloro, F. Assessing the fish assemblage associated with FADs (Fish Aggregating Devices) in the southern Tyrrhenian Sea using two different professional fishing gears. Fish. Res. 2012, 123 , 56-61. [CrossRef]

66. Suaria, G.; Aliani, S. Floating debris in the Mediterranean Sea. Mar. Pollut. Bull. 2014, 86, 494-504. [CrossRef]

67. Giani, M.; Djakovac, T.; Degobbis, D.; Cozzi, S.; Solidoro, C.; Umani, S.F. Recent changes in the marine ecosystems of the northern Adriatic Sea. Estuar. Coast. Shelf Sci. 2012, 115, 1-13. [CrossRef]

68. Tugores, M.P.; Giannoulaki, M.; Iglesias, M.; Bonanno, A.; Tičina, V.; Leonori, I.; Machias, A.; Tsagarakis, K.; Díaz, N.; Giráldez, A.; et al. Habitat suitability modelling for sardine Sardina pilchardus in a highly diverse ecosystem: The Mediterranean sea. Mar. Ecol. Prog. Ser. 2011, 443, 181-205. [CrossRef]

69. Moltó, V.; Hernández, P.; Sinopoli, M.; Besbes-Benseddik, A.; Besbes, R.; Mariani, A.; Gambin, M.; Alemany, F.; Morales-Nin, B.; Grau, A.M.; et al. A global review on the biology of the dolphinfish (Coryphaena hippurus) and its fishery in the Mediterranean Sea: Advances in the last two decades. Rev. Fish. Sci. Aquac. 2020, 28, 376-420. [CrossRef]

70. Campo, D.; Mostarda, E.; Castriota, L.; Scarabello, M.P.; Andaloro, F. Feeding habits of the Atlantic bonito, Sarda sarda (Bloch, 1793) in the southern Tyrrhenian sea. Fish. Res. 2006, 81, 169-175. [CrossRef]

71. Moreno, A.; Boavida-Portugal, J.; Pimentel, M.; Pereira, J.; Rosa, R. Loligo vulgaris, European Squid. In Advances in Sqid Biolgy, Eclogy and Fisheies; Rosa, R., O’Dor, R., Pierce, G., Eds.; Nova Biomedical, Nova Science Publishers, Inc.: New York, NY, USA, 2013; pp. 3-32.

72. Pešić, A.; Đurović, M.; Joksimović, A.; Regner, S.; Simonović, P.; Glamuzina, B. Some reproductive patterns of the sardine, Sardina pilchardus (Walb, 1792), in Boka Kotorska Bay (Montenegro, southern Adriatic Sea). Acta Adriat. 2010, 52, $159-168$.

73. Batistić, M.; Tutman, P.; Bojanić, D.; Skaramuca, B.; Kožul, V.; Glavić, N.; Bartulović, V. Diet and diel feeding activity of juvenile pompano (Trachinotus ovatus) (Teleostei: Caranghidae) from the southern Adriatic, Croatia. J. Mar. Biol. Assoc. U.K. 2005, 85, 1533-1534. [CrossRef]

74. Dulčić, J.; Pallaoro, A.; Kraljević, M. First record of pompano fingerling Trachinotus ovatus (Linnaeus, 1758) (Pisces: Carangidae) in the eastern middle Adriatic. Nat. Croat. 1997, 1, 61-65.

75. Lipej, L.; Dulčić, J. The current status of Adriatic fish biodiversity. In Balkan Biodiversity: Pattern and Process in the European Hotspot; Griffiths, H.I., Kryštufek, B., Reed, J.M., Eds.; Kluwer Academic Publishers: Dordrecht, The Netherlands, 2004; pp. 291-306.

76. Dulčić, J.; Pallaoro, A.; Kraljević, M. Occurrence of bluefish, Pomatomus saltator (Linnaeus, 1766), and butterfish, Stromateus fiatola (Linnaeus, 1758), juveniles in the eastern central Adriatic. Ann. Ser. Hist. Nat. 2000, 19, 19-22.

77. Sabatés, A.; Martín, P.; Raya, V. Changes in life-history traits in relation to climate change: Bluefish (Pomatomus saltatrix) in the northwestern Mediterranean. ICES J. Mar. Sci. 2012, 69, 1000-1009. [CrossRef]

78. Cengiz, O.; Ozekinci, U.; Oztekin, A.; Kumova, C. Growth parameters and mortality of bluefish (Pomatomus saltatrix Linneaus, 1766) from Gallipoli peninsula and Dardanelles (northeastern Mediterranean, Turkey). Mar. Sci. Tech. Bull. 2013, 2, 1-7.

79. Sepulveda, M.; Oliva, D. Interactions between South American sea lions Otaria flavescens (Shaw) and salmon farms in southern Chile. Aquac. Res. 2005, 36, 1062-1068. [CrossRef]

80. Sanchez-Jerez, P.; Fernandez-Jover, D.; Bayle-Sempere, J.; Valle, C.; Dempster, T.; Tuya, F.; Juanes, F. Interactions between bluefish Pomatomus saltatrix (L.) and coastal sea-cage farms in the Mediterranean Sea. Aquaculture 2008, 282, 61-67. [CrossRef]

81. Dulčić, J.; Kraljević, M.; Pallaoro, A.; Glamuzina, B. Unusual catch of bluefish Pomatomus saltatrix (Pomatomidae) in Tarska cove (northern Adriatic). Cybium 2005, 29, 207-208. 
82. Grati, F.; Scarcella, G.; Bolognini, L.; Fabi, G. Releasing of the European sea bass Dicentrarchus labrax (Linnaeus) in the Adriatic Sea: Large-volume versus intensively cultured juveniles. J. Exp. Mar. Biol. Ecol. 2011, 397, 144-152. [CrossRef]

83. Whitfield, A.K. The role of seagrass meadows, mangrove forests, salt marshes and reed beds as nursery areas and food sources for fishes in estuaries. Rev. Fish. Biol. Fish. 2017, 27, 75-110. [CrossRef]

84. Iveša, N.; Špelić, I.; Gelli, M.; Castellicchio, A.; Piria, M.; Gavrilović, A. Fish catch analysis of the "poponica" net in Bay of Medulin. In Proceedings of the 2020, 55th Croatian \& 15th International Symposium on Agriculture, Vodice, Croatia, 17-21 February 2020; pp. 328-333. 